ISSN 2083-3725
Authors' contribution/

Wkład autorów:

A. Zaplanowanie badań/

Study design

B. Zebranie danych/

Data collection

C. Analiza statystyczna/

Statistical analysis

D. Interpretacja danych/

Data interpretation

E. Przygotowanie tekstu/

Manuscript preparation

F. Opracowanie

piśmiennictwa/

Literature search

G. Pozyskanie funduszy/

Funds collection

\section{ESTIMATION OF ENERGY DEMAND IN A TERRITORIAL GOVERNMENT UNIT - METHODOLOGICAL PROBLEMS}

\author{
SZACOWANIE ZAPOTRZEBOWANIA NA ENERGIE JEDNOSTKI \\ TERYTORIALNEJ - PROBLEMY METODYCZNE
}

\author{
Alina Kowalczyk-Juśko ${ }^{1(A, B, C, D, E)}$, Bogdan Kościk ${ }^{2(E, F, G)}$
}

${ }^{1}$ Uniwersity of Life Sciences in Lublin

Uniwersytet Przyrodniczy w Lublinie

${ }^{2}$ Pope John Paul II State School of Higher Education in Biała Podlaska

Państwowa Szkoła Wyższa im. Papieża Jana Pawła II w Białej Podlaskiej

Kowalczyk-Juśko A., Kościk B. (2017), Estimation of energy demand in a territorial government unit -methodological problems/Szacowanie zapotrzebowania na energie jednostki terytorialnej - problemy metodyczne. Economic and Regional Studies, Vol. 10, No. 3, pp. 5-16. https://doi.org/10.2478/ers-2017-0020

\section{Summary}

\section{ORIGINAL ARTICLE}

JEL code: Q31, Q41, Q47, R58

Subject and purpose of work: The aim of the study is to identify methodological problems, which may be encountered during the preparation of the energy balance of a territorial unit, along with indications of ways to solve them. Materials and methods: Problems were identified during the preparation of the energy balance for two selected rural communes and then they were investigated with reference to the literature on this subject. Results: Estimating the energy demand of a local government unit requires proper identification of the groups of energy consumers, divided into facilities owned or co-owned by communes and ones independent from commune authorities. The latter group is divided further, into households, businesses, farms. For each of the users different methods of obtaining data may be needed: a survey and analysis of statistical data, analysis of financial documents, evaluation of the buildings' age. Generally, however, preparing an energy balance statement requires many simultaneous approaches, and the combination of multi-criterion analysis provides the most reliable picture of the problem. Conclusions: The scope of the data needed to compile an energy balance statement for local government units, depends on the purpose of the developed analysis. Methodological handbooks and training materials on this subject are helpful, but the developed methodologies may need to be modified and adapted to specific conditions.

Keywords: energy balance, energy demand, energy consumption, methodology

\section{Streszczenie}

Przedmiot i cel pracy: Celem pracy jest wskazanie problemów metodycznych, na jakie napotkać można podczas sporządzania bilansu energetycznego jednostki terytorialnej, wraz ze wskazaniami sposobów ich rozwiązania. Materiały i metody: Problemy zidentyfikowano podczas sporządzania bilansu energetycznego dwu wybranych gmin wiejskich, a następnie skonfrontowano z literaturą przedmiotu. Wyniki: Oszacowanie zapotrzebowania na energię w jednostce samorządu terytorialnego wymaga właściwego określenia grup odbiorców energii w podziale na obiekty będące własnością lub współwłasnością gminy oraz niezależne od władz gminy. Druga grupa dzieli się dalej, na gospodarstwa domowe, przedsiębiorstwa, gospodarstwa rolne. Dla każdej z grup odbiorców mogą być potrzebne odmienne metody pozyskania danych: badanie ankietowe, analiza danych statystycznych, analiza dokumentów finansowych, ocena wieku budynków. Najczęściej jednak sporządzenie bilansu energetycznego wymaga stosowania wielu podejść równocześnie, a połączenie wyników analizy wielokryterialnej daje najbardziej rzetelny obraz badanego problemu. Wnioski: Zakres danych, potrzebnych do sporządzenia bilansu energetycznego jednostki samorządu terytorialnego, zależy od celu opracowania analizy. Poradniki metodyczne i materiały szkoleniowe na ten temat są pomocne, jednak opracowane metodyki mogą wymagać modyfikacji i dostosowania do konkretnych warunków.

Słowa kluczowe: bilans energetyczny, zapotrzebowanie na energię, zużycie energii, metodyka

Address for correspondence/ Adres korespondencyjny: dr inż. Alina Kowalczyk-Juśko, Uniwersytet Przyrodniczy w Lublinie, ul. Leszczyńskiego 7, 20-950 Lublin, Poland; phone: +48 694-561-382, e-mail: alina.jusko@up.lublin.pl;; prof. dr hab. Bogdan Kościk, Państwowa Szkoła Wyższa im. Papieża Jana Pawła II w Białej Podlaskiej, ul. Sidorska 95/97, 21-500 Biała Podlaska, Poland; phone: +48 83 344-99-05; e-mail: bogdan.koscik48@gmail.com;

Journal indexed in/ Czasopismo indeksowane w: AgEcon Search, AGRO, BazEkon, Index Copernicus Journal Master List, ICV 2016: 92,91; Polish Ministry of Science and Higher Education 2016: 9 points/ AgEcon Search, AGRO, BazEkon, Index Copernicus Journal Master List ICV 2016: 92.91; Ministerstwie Nauki i Szkolnictwa Wyższego 2016: 9 punktów. Copyright: (C) 2017 Pope John Paul II State School of Higher Education in Biała Podlaska, Alina Kowalczyk-Juśko, Bogdan Kościk. All articles are distributed under the terms of the Creative Commons Attribution-NonCommercial-ShareAlike 4.0 International (CC BY-NC-SA 4.0) License (http://creativecommons.org/licenses/bync-sa/4.0/), allowing third parties to copy and redistribute the material in any medium or format and to remix, transform, and build upon the material, provided the original work is properly cited and states its license. 


\section{Introduction}

Theresponsibilities of a commune, as a basicunit of local government, include organizing and executing the supply of heat, electricity and fuel gas on its territory, in accordance with the assumptions of the "Polish Energy Policy until 2030" (Policy ... 2009). The changing environment requires preparation of various studies, strategies, applications for external financing of measures undertaken by the commune, etc., as well as their verification. The strategic and planning documents often require estimation of energy consumption by different entities located in a given area. Because of the wide variety of energy consumers, credible assessment of the demand for electricity, heat and fuel can be laborious and can require collecting a substantial amount of data. To standardize testing methods and to facilitate their performance, studies in the form of guides are created. They are useful in the preparation of various documents directly related to the consumption and production of energy (plans for energy supply, lowcarbon strategies for renewable energy sources, etc.), and those in which the consumption of energy is one of many issues (Bertoldi et al. 2012; Rusak 2011; Zarządzanie... 2009). The level of detail in analyses may vary: from cursory, roughly estimated to a meticulous inventory of both energy users broken down into types of energy, duration and amount of consumption, and the possibilities of its production.

The preparation of energy balance requires the collection of a range of data about the area for which it is developed. These include demographic, spatial and economic features. The most reliable results can be obtained using possibly most up-to-date data on a given commune (NTS 5). In the case of information unavailability, it is possible to use statistical data on higher levels of classification: the county (NTS 4), the sub-region (NTS 3 ) and the province (NTS 2), which is burdened with a greater error.

One of the sources of energy consumption data can be operators of fuel and energy market. Since the liberalization of the natural gas and electricity market, the number of its participants has increased and the energy consumption data are becoming commercially sensitive, thus making their acquisition from energy suppliers increasingly difficult. Valuable data may be available at a regional or national level they can be held by ministries or agencies responsible for statistics, energy, environment, economy, etc. If the data cannot be obtained in the desired format from the operators of fuel and energy market or from other entities, turning directly to the energy consumers, e.g. through surveys may be required. This is especially true in the case of energy, which is not distributed through a centralized network (coal, heating oil, wood).

Collecting information from every individual energy consumer within a town or commune is not always possible or practical. Therefore, it may be necessary to use several different approaches to estimate energy consumption in different sectors. To

\section{Wstęp}

W zakresie obowiązków gminy, jako podstawowej jednostki samorządu terytorialnego, znajduje się organizowanie i realizacja zaopatrzenia w ciepło, energię elektryczną i paliwa gazowe na swoim terenie, zgodnie z założeniami „Polityki Energetycznej Polski do roku 2030" (Polityka... 2009). Zmieniające się otoczenie wymaga sporządzania różnych opracowań, strategii, wniosków o finansowanie zewnętrzne działań podejmowanych przez gminę itp., a także ich weryfikacji. Dokumenty planistyczne i strategiczne wymagają często oszacowania zużycia energii przez różne podmioty zlokalizowane na danym terenie. Ze względu na dużą różnorodność konsumentów energii wiarygodna ocena zapotrzebowania na prąd, ciepło i paliwa może okazać się pracochłonna i wymagać zebrania wielu danych. Aby ujednolicić metody badań i ułatwić ich przeprowadzenie powstają opracowania o charakterze poradników, które są pomocne przy sporządzaniu różnych dokumentów, związanych bezpośrednio ze zużyciem i wytwarzaniem energii (plany zaopatrzenia w energię, plany gospodarki niskoemisyjnej, strategie rozwoju odnawialnych źródeł energii itp.), a także takich, w których temat zużycia energii jest jednym z wielu zagadnień (Bertoldi i in. 2012; Rusak 2011; Zarządzanie... 2009). Poziom szczegółowości analiz może być bardzo różny: od pobieżnych, zgrubnych oszacowań, do drobiazgowej inwentaryzacji zarówno podmiotów zużywających energię w podziale na rodzaje energii, czas i wielkość zużycia, jak też możliwości jej wytwarzania.

Sporządzenie bilansu energetycznego wymaga zebrania szeregu danych na temat obszaru, dla którego jest opracowywany. Obejmują one cechy demograficzne, przestrzenne i gospodarcze. Najbardziej wiarygodne wyniki można uzyskać korzystając z możliwie aktualnych danych dotyczących danej gminy (NTS 5). W przypadku braku dostępności informacji możliwe jest wykorzystanie danych statystycznych na wyższych poziomach klasyfikacji: powiatu (NTS 4), podregionu (NTS 3) i województwa (NTS 2), co jest obarczone większym błędem.

Jednym ze źródeł danych dotyczących zużycia energii mogą być operatorzy rynku paliw i energii. Od czasu liberalizacji rynku gazu ziemnego i energii elektrycznej wzrosła liczba jego uczestników, a dane dotyczące zużycia energii stają się komercyjnie wrażliwe, przez co ich pozyskanie od dostawców energii staje się coraz trudniejsze. Wartościowe dane mogą być dostępne na szczeblu regionalnym lub krajowym - w ich posiadaniu mogą być ministerstwa lub agencje właściwe ds. statystyki, energii, środowiska czy gospodarki itp. Jeżeli nie da się pozyskać danych w pożądanym formacie od operatorów rynku paliw i energii lub od innych podmiotów, konieczne może okazać się zwrócenie się z zapytaniem bezpośrednio do konsumentów energii np. poprzez badania ankietowe. Ma to miejsce zwłaszcza w przypadku nośników energii, które nie są dystrybuowane za pomocą scentralizowanej sieci (węgiel kamienny, olej opałowy, drewno). 
obtain a complete picture of the energy consumption in a given commune, most often it is necessary to use their combination (Bertoldi et al. 2012).

\section{Characteristics of energy users}

Estimating the local demand for energy in a commune requires identification of the components of the local energy system. Local energy management at the commune level consists of (Rusak 2011):

A. Objects and power equipment, whose work, scope, financing and direction of development is directly dependent on the decisions of the commune:

- communal office buildings,

- schools and kindergartens,

- clinics, hospitals,

- social and subsidised housing,

- sports and cultural facilities,

- sewage treatment plants, waterworks,

- other facilities, owned or co-owned by the commune.

B. Facilities and energy equipment being private property or owned by companies which are not connected with the commune, whose condition and development is financed from funds other than communal:

- detached houses and multi-household buildings,

- production and retail companies,

- farms,

- buildings of institutions independent of the commune.

This division is justified by competence division at the communal level: for facilities and power equipment, whose operation is directly dependent on the commune (group A) definite decisions can be made to define the directions of development and changes, while the commune does not have instruments to directly influence the behavior of the components of the energy system (generating and receiving ones) which are beyond its control (group B). The execution of communal energy policy in relation to the B scope is possible with the use of indirect instruments of exerting influence: educational ones (in cooperation with domestic and foreign organizations, promoting rational use of energy) or ones from the field of planning. In exceptional cases, it is possible to impose certain obligations through regulations of local legislation, an example of which is the prohibition on burning solid fuels, resulting from environmental pollution, introduced periodically by some local governments (Bukowski 2012).

In households, micro-enterprises and farms the basic form of final energy is heat. This form of energy can be obtained by users in two ways: by producing it on their own in boilers for heating individual buildings or by using the heat generated in heating plants or power plants. Estimating the consumption
Zbieranie informacji od każdego indywidualnego konsumenta energii na obszarze miasta lub gminy nie zawsze jest możliwe lub praktyczne. Dlatego też konieczne może okazać się zastosowanie kilku różnych podejść, które pozwolą oszacować zużycie energii w poszczególnych sektorach. Aby uzyskać pełny obraz zużycia energii na terenie gminy, najczęściej konieczne jest zastosowanie ich kombinacji (Bertoldi i in. 2012).

\section{Charakterystyka użytkowników energii}

Oszacowanie lokalnego zapotrzebowania na energię w gminie wymaga zidentyfikowania elementów lokalnego systemu energetycznego. Na lokalną gospodarkę energetyczną na szczeblu gminy składają się (Rusak 2011):

A. Obiekty i urządzenia energetyczne, których praca, zakres, finansowanie i kierunek rozwoju zależny jest bezpośrednio od decyzji gminy:

- budynki urzędu gminy,

- szkoły i przedszkola,

- przychodnie, szpitale,

- mieszkania socjalne i komunalne,

- obiekty sportowe i kulturalne,

- oczyszczalnie ścieków, wodociągi,

- inne obiekty, będące własnością lub współwłasnością gminy.

B. Obiekty i urządzenia energetyczne będące własnością prywatną lub firm nie związanych z gminą, których stan i rozwój finansowany jest z funduszy innych niż gminne:

- budynki mieszkalne indywidualne i wielorodzinne,

- przedsiębiorstwa produkcyjne i handlowe,

- gospodarstwa rolne,

- budynki instytucji niezależnych od gminy.

Podział ten uzasadniony jest kompetencjami na szczeblu gminy: dla obiektów i urządzeń energetycznych, których praca jest bezpośrednio zależna od gminy (grupa A) mogą być podejmowane decyzje jednoznacznie określające kierunki rozwoju i zmian, natomiast gmina nie ma instrumentów bezpośredniego wpływania na zachowania elementów systemu energetycznego (wytwórczych i odbiorczych) od niej niezależnych (grupa B). Realizacja gminnej polityki energetycznej w odniesieniu do zakresu B możliwa jest przy wykorzystaniu pośrednich instrumentów oddziaływania: edukacyjnych (współpraca z krajowymi i zagranicznymi organizacjami propagującymi racjonalne użytkowanie energii) czy planistycznych. W wyjątkowych sytuacjach możliwe jest nałożenie pewnych obowiązków przez przepisy prawa lokalnego, czego przykładem jest zakaz spalania paliw stałych, wynikający z zanieczyszczenia środowiska, wprowadzany okresowo przez niektóre samorządy (Bukowski 2012).

W gospodarstwach domowych, mikroprzedsiębiorstwach i gospodarstwach rolnych podstawową formą energii finalnej jest ciepło. Tę formę energii użytkownicy mogą pozyskać dwojako: wytwarzając ją we własnym zakresie $w$ kotłach przeznaczonych do ogrzewania indywidualnych obiektów lub wykorzystując 
of heat and fuel in rural communities, where there is no heating supply network, is more difficult and far more labour-intensive than in the case of analysing urban areas, where the demand is largely covered by centralized sources.

The research carried out in recent years in Poland on rural communes in south-eastern Poland demonstrated variability in heat demand per one inhabitant (Mk) for the surveyed communes, in the range from 17.4 to 44.6 , with an average of 26.2 GJ / Mk (Trojanowska, Szul 2008). The difficulty with such estimates is that the research and the coefficients of energy consumption for heating and hot water generation, based on it, become outdated over time. In addition, research carried out for one community may not be representative for another one, particularly with regard to the communes located in various parts of the country. This is due to different climatic conditions, availability of certain types of fuel in a given area, etc.

A much higher functional diversity is related to the use of electricity of the recipients in category B. Electric receivers in each of the featured groups have other functions, adapted to the tasks, which have devices powered by electricity in each group of recipients.

\section{The estimation of energy demand in communal facilities}

Facilities owned by the commune, which are primarily residential (government-subsidised housing) and public utility buildings. With regard to residential buildings, the estimation of energy consumption can be carried out on the basis of the data of enterprises trading in energy or directly: based on energy bills and fuel. This research can be performed on a selected sample of representative facilities, or on all facilities, which is possible in small communities, especially in rural areas. ciepło wytwarzane $\mathrm{w}$ ciepłowniach lub elektrociepłowniach. Oszacowanie zużycia ciepła i paliw w gminach wiejskich, w których nie ma sieci ciepłowniczych, jest trudniejsze i znacznie bardziej pracochłonne niż w przypadku analizy obszarów zurbanizowanych, na których zapotrzebowanie w znacznym stopniu pokrywane jest przez scentralizowane źródła.

Badania wykonywane w ostatnich latach w Polsce dla gmin wiejskich południowo-wschodniej Polski wykazały zmienność zapotrzebowania na ciepło w odniesieniu do jednego mieszkańca (Mk) dla badanych gmin w zakresie od 17,4 do 44,6 przy średniej równej 26,2 GJ/Mk (Trojanowska, Szul 2008). Utrudnieniem $w$ takich oszacowaniach jest to, że badania i na ich podstawie wyprowadzone współczynniki zużycia energii na ogrzewanie i przygotowanie ciepłej wody uży tkowej dezaktualizują się z czasem. Ponadto badania wykonane dla jednej gminy nie muszą być reprezentatywne dla innej, szczególnie w odniesieniu do gmin położonych w różnych częściach kraju. Wynika to z innych warunków klimatycznych, dostępności określonych typów paliwa na danym obszarze itp.

Znacznie większe zróżnicowanie funkcjonalne dotyczy sposobów użytkowania energii elektrycznej u odbiorców kategorii B. Odbiorniki elektryczne w każdej z wyróżnionych grup spełniają inne funkcje, dostosowane do zadań, które mają urządzenia zasilane energią elektryczną w poszczególnych grupach odbiorców.

\section{Szacowanie zapotrzebowania na energię $w$ obiek- tach gminnych}

Obiekty będące własnością gminy, to przede wszystkim obiekty mieszkalne (mieszkania komunalne) oraz budynki użyteczności publicznej. W odniesieniu do budynków mieszkalnych oszacowanie zużycia energii można przeprowadzić na podstawie danych przedsiębiorstw obrotu energią lub bezpośrednio: w oparciu o rachunki za energię i paliwa. Badania te można przeprowadzić na wybranej próbie reprezentatywnych obiektów, lub we wszystkich obiektach, co jest możliwe w niewielkich gminach, szczególnie wiejskich.

Table 1. Reference values for the estimation of electricity consumption for lighting in public utility buildings

Tabela 1. Wartości referencyjne do oszacowania zużycia energii elektrycznej na oświetlenie dla budynków użyteczności publicznej

\begin{tabular}{|l|c|c|}
\hline \multicolumn{1}{|c|}{$\begin{array}{c}\text { Type of building/ } \\
\text { Typ budynku }\end{array}$} & $\begin{array}{c}\text { Reference electric } \\
\left.\text { power [W/m }{ }^{2}\right] / \text { Lighting service } \\
\text { Moc elektryczna re- } \\
\text { ferencyjna [W/m2] }\end{array}$ & $\begin{array}{c}\text { time [h/year]/ } \\
\text { Czas uźytkowania } \\
\text { oświetlenia [h/rok] }\end{array}$ \\
\hline Institutions and offices/ Biura i urzędy & 20 & 2500 \\
\hline Schools/ Szkoły & 20 & 2000 \\
\hline Hospitals/ Szpitale & 25 & 5000 \\
\hline Restaurants, catering/ Restauracje, gastronomia & 25 & 2500 \\
\hline Railway stations, bus stations, airports/ Dworce kolejowe, autobusowe, lotnicze & 20 & 4000 \\
\hline Shopping and services/ Handlowo - usługowe & 25 & 5000 \\
\hline Sports and recreation/ Sportowo-rekreacyjne & 20 & 2500 \\
\hline
\end{tabular}


For the part of the public utility facilities the projected unit consumption of electricity used for lighting $\left[\mathrm{kWh} / \mathrm{m}^{2}\right]$ can be determined on the basis of the regulation by the Minister of Infrastructure on technical conditions which should be met by buildings and their location (Table 1).

In proprietary studies, the current demand for electricity and heat in buildings owned by the commune, was established on the basis of the data provided by communal offices, based on the current record of energy consumption, electricity bills and bills for the purchase of fuels for heating purposes. The obtained data, in some cases, were expressed as the amount of energy, and in others as the amount of fuel consumed. Considering that in particular facilities different fuels were used in order to express their energy consumption in units, we adopted calorific values provided annually by the National Centre for Emissions Balancing and Management (Values ... 2016).

\section{The estimation of the demand for electricity in households}

Energy demand at the level of a territorial unit, is a component of the energy needs of households and depends de facto on the energy management of individual residents in a given area and the level of their wealth. It has been shown that energy consumption in households with a high income per capita is usually higher compared to lower income families with more frugal management (Rusak 2011).

Households are a fairly homogeneous group of energy consumers, both in the form of heat and electricity. The main energy need of households is the heat used for heating living quarters and hot water generation. The amount of primary energy consumption for generating heat energy is dependent on the usable surface of a building (apartment), age and technical characteristics of the building, the condition of the heating system, and the number of people living in the household, which determines the amount of energy used for hot water preparation. The energy consumption of households is determined by the energy used for the requirements of maintaining thermal comfort, because it represents about $69 \%$ of the total amount of energy consumed. The remaining energy requirements account for approximately $31 \%$ of the total energy used in the house, which consists of the energy used for the preparation of meals, lighting and powering various electricityconsuming appliances (Fig. 1).

Electricity consumption in households depends largely on the income of the family, because it determines the household equipment in electricityconsuming appliances, as well as their utilisation. In households, whose residents obtain low income, electrical appliances are used in a more costeffective manner, for example: turning off the refrigerator during winter, installing less powerful bulbs etc. We can also observe large differences in
Dla części obiektów użyteczności publicznej jednostkowa prognozowana wielkość zużycia energii elektrycznej zużywanej na oświetlenie $\left[\mathrm{kWh} / \mathrm{m}^{2}\right]$ może być określona na podstawie rozporządzenia Ministra Infrastruktury w sprawie warunków technicznych, jakim powinny odpowiadać budynki i ich usytuowanie (tabela 1).

W badaniach własnych bieżące zapotrzebowanie na energię elektryczną i cieplną w budynkach, będących własnością gminy, ustalono na podstawie danych udostępnionych przez urzędy gmin, w oparciu o aktualną ewidencję zużycia energii, rachunki za zużycie energii elektrycznej oraz rachunki za zakup paliw dla celów grzewczych. Uzyskane dane w niektórych przypadkach wyrażone były w ilościach energii, w innych zaś w ilości zużytych paliw. W związku z tym, że w poszczególnych obiektach stosowane były różne paliwa, w celu wyrażenia ich zużycia w jednostkach energetycznych przyjęto wartości opałowe podawane corocznie przez Krajowy Ośrodek Bilansowania i Zarządzania Emisjami (Wartości... 2016).

\section{Szacowanie zapotrzebowania na energię elek- tryczną w gospodarstwach domowych}

Zapotrzebowanie na energię na poziomie jednostki terytorialnej, stanowi składową potrzeb energetycznych gospodarstw domowych, uzależnione jest więc de facto od gospodarowania energią poszczególnych mieszkańców danego obszaru i poziomu ich zamożności. Dowiedziono, że zużycie energii w gospodarstwach domowych o wysokim dochodzie na mieszkańca najczęściej jest wyższe w porównaniu do oszczędnie gospodarujących rodzin o niższych dochodach (Rusak 2011).

Gospodarstwa domowe stanowią dość jednorodną grupę odbiorców energii, zarówno w postaci ciepła, jak i energii elektrycznej. Główne potrzeby energetyczne w gospodarstwach domowych to ciepło wykorzystywane do ogrzewania pomieszczeń mieszkalnych i do przygotowania ciepłej wody użytkowej. Wielkość zużycia energii pierwotnej na potrzeby wytworzenia energii cieplnej zależna jest od powierzchni budynku (mieszkania), wieku i właściwości technicznych budynku, stanu instalacji grzewczej, oraz od liczby osób zamieszkujacych w gospodarstwie domowym, od której zależy ilość energii zużywanej na przygotowanie ciepłej wody użytkowej. O energochłonności gospodarstw domowych decyduje energia wykorzystywana na potrzeby zachowania komfortu cieplnego, ponieważ stanowi około $69 \%$ całkowitej ilości zużywanej energii. Pozostałe potrzeby energetyczne wykorzystują około $31 \%$ całości energii zużywanej w domu, na co składa się energia wykorzystywana na przygotowanie posiłków, oświetlenie oraz zasilanie różnych odbiorników elektrycznych (rys. 1).

Zużycie energii elektrycznej w gospodarstwach domowych zależne jest $\mathrm{w}$ dużym stopniu od wysokości dochodów danej rodziny, gdyż to determinuje wyposażenie gospodarstwa domowego $\mathrm{w}$ odbiorniki energii elektrycznej, a także ich użytkowanie. W gospodarstwach domowych, których mieszkańcy uzyskują niskie dochody, urządzenia elektryczne użytkowane 


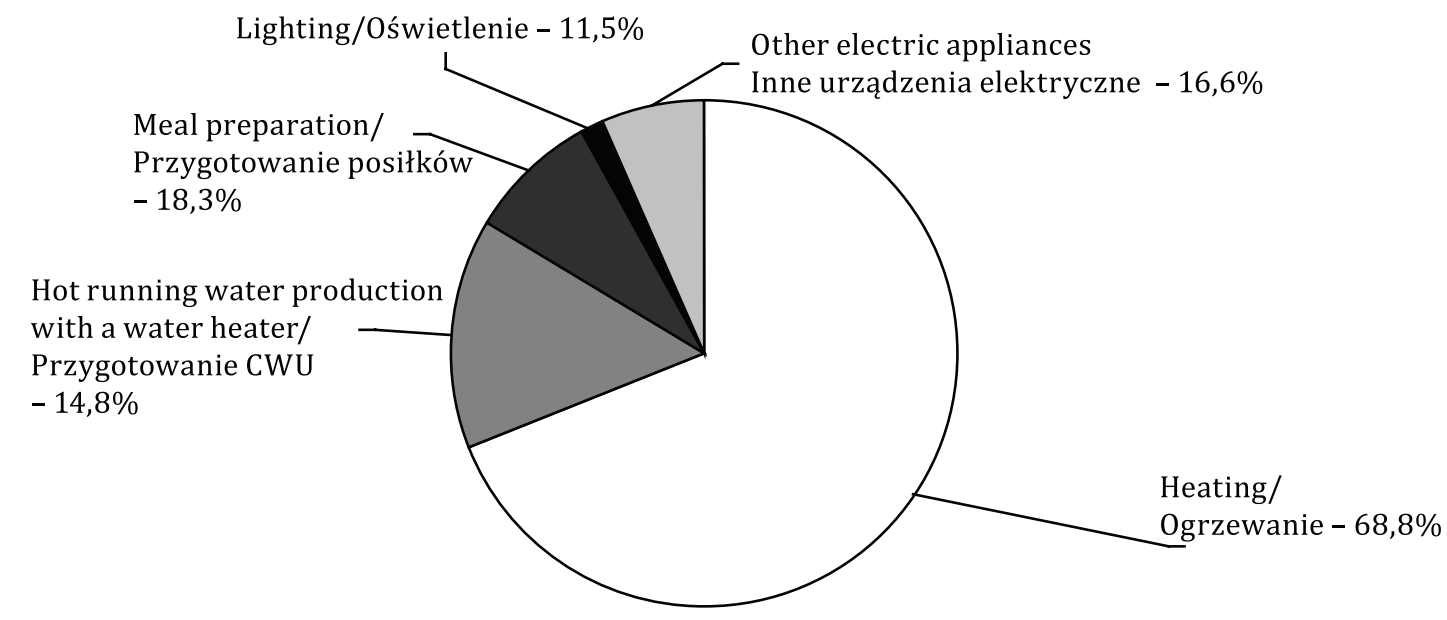

Figure 1. The structure of the final energy consumption in households in 2012

Rysunek 1. Struktura wykorzystania energii finalnej w gospodarstwach domowych w $2012 \mathrm{r}$.

Source: The efficiency... 2015.

Źródło: Efektywność... 2015.

power consumption in rural households in particular provinces (Table 2). Also, the magnitude of changes in this rate noted in 2002-2010 is worth mentioning. Average consumption in Poland increased during this period approx. 2-fold, but in Podlaskie Province the increase was more than 5-fold (from 171 to $875 \mathrm{kWh} /$ person). Such large regional differences from in energy consumption poses methodological problems during the preparation of energy balance. So, it is important to use possibly the most precise data at the province level and, if possible, at the communal level. są w bardziej oszczędny sposób, np. wyłączanie lodówki na zimę, instalowanie żarówek o mniejszej mocy itp. Obserwuje się też duże różnice w zużyciu prądu w wiejskich gospodarstwach domowych w poszczególnych województwach (tab. 2). Na uwagę zasługuje też wielkość zmian tego wskaźnika, jakie odnotowano w latach 2002-2010. Srednie zużycie w Polsce wzrosło w tym okresie ok. 2-krotnie, jednak np. w woj. podlaskim był to wzrost ponad 5-krotny (ze 171 do 875 kWh/osobę). Tak duże zróżnicowanie regionalne pod kątem zużycia energii nastręcza problemy metodyczne podczas sporządzania bilansu energetycznego,

Table 2. The consumption of electricity in rural households per province

Tabela 2. Zużycie energii elektrycznej w wiejskich gospodarstwach domowych według województw

\begin{tabular}{|c|c|c|c|c|}
\hline \multirow{2}{*}{$\begin{array}{c}\text { Provinces/ } \\
\text { Województwa }\end{array}$} & \multicolumn{2}{|c|}{ The consumption of electricity/ Zużycie energii elektrycznej } \\
\cline { 2 - 5 } & \multicolumn{2}{|c|}{ [GWh] } & \multicolumn{2}{c|}{$\begin{array}{c}\text { per 1 inhabitant [kWh]/ } \\
\text { na 1 mieszkańca [kWh] }\end{array}$} \\
\cline { 2 - 5 } & $\mathbf{2 0 0 2}$ & $\mathbf{2 0 1 0}$ & $\mathbf{2 0 0 2}$ & $\mathbf{2 0 1 0}$ \\
\hline Poland/ Polska & 5531,2 & 11368,3 & 378,2 & 754,5 \\
\hline Dolnośląskie & 379,4 & 654,1 & 456,2 & 810,8 \\
\hline Kujawsko-Pomorskie & 359,7 & 669,1 & 460,4 & 653,1 \\
\hline Lubelskie & 267,9 & 761,7 & 228,3 & 756,8 \\
\hline Lubuskie & 162,5 & 261,9 & 454,1 & 781,9 \\
\hline tódzkie & 255,8 & 716,8 & 279,5 & 751,3 \\
\hline Małopolskie & 592,1 & 1269,0 & 368,5 & 837,7 \\
\hline Mazowieckie & 572,3 & 1576,1 & 315,9 & 945,8 \\
\hline Oppolskie & 255,1 & 458,3 & 505,5 & 533,8 \\
\hline Podkarpackie & 291,0 & 664,3 & 232,6 & 875,1 \\
\hline Podlaskie & 85,1 & 419,3 & 171,0 & 818,7 \\
\hline Pomorskie & 363,3 & 631,7 & 522,1 & 837,0 \\
\hline Śląskie & 629,0 & 857,5 & 634,2 & 582,1 \\
\hline Ślwięrokrzysie & 156,6 & 409,8 & 223,0 & 775,1 \\
\hline Warmińsko-Mazurskie & 251,0 & 456,0 & 441,6 & 792,2 \\
\hline Wielkopolskie & 671,0 & 1198,5 & 473,3 & 644,8 \\
\hline Zachodniopomorskie & 239,4 & 344,3 & 462,1 & \\
\hline
\end{tabular}

Source: Common... 2011.

Źródło: Powszechny... 2011. 
The tendency towards increasing energy consumption in households, which took place in 2002-2010, has been stopped in recent years, due to the use of energy-saving building materials in new buildings and the thermal modernisation of older buildings (replacement of windows, insulation, replacement of heating appliances).

In our study estimating current electricity consumption in households is based on the literature data and the available statistical data verified on the basis of surveys.

The Central Statistical Office (CSO) publishes annual statistical data related to the functioning of the national energy system. This information includes, among others, the amount of annual energy consumption by households per one person [kWh/ person/year].

In order to prepare an energy balance statement for a commune, the amount of energy consumed collectively by all households $\left(\mathrm{A}_{\mathrm{GD}}\right)$ was calculated using the following formula:

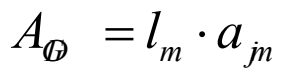

where:

$$
\begin{aligned}
& l_{m}-\text { The number of population in the analysed } \\
& \text { area, } \\
& a_{j m}-\text { specific electricity consumption of } \\
& \text { households per capita [kWh/person/year]. }
\end{aligned}
$$

The $\mathrm{a}_{\text {im }}$ indicator was adopted at the specified level for NTS 4. In order to assess the reliability of the calculations carried out on the basis of statistical data, the analysis was supplemented with survey results. Depending on the purpose of research, the form of the survey should be constructed in a way which allows for estimating:

- the average annual energy consumption in households in kWh/year,

- the average annual energy consumption in households per capita in $\mathrm{kWh} /$ year/person,

- the average annual energy consumption per $\mathrm{m}^{2}$ of floor area,

- to select periods of the lowest and the highest energy consumption as well as to establish the difference between these values.

The establishment of a link between the expressed opinions of respondents and their actual behavior can be a methodological problem in the analysis based on surveys. An attempt to reconstruct a link between these concepts is especially important, when the research tool is a questionnaire, from which conclusions are drawn on the basis of respondents' declarations, not by direct observation of their behavior. In this way, an area of uncertainty arises, with regard to whether the responses will be reflected in real actions. It is not assumed, that the respondents intentionally provide false answers, but there are doubts about how much the responses stem from attempting to adjust to the generally accepted principles (Sidorczuk-Pietraszko, Zawistowska 2011). dlatego należy posługiwać się możliwie precyzyjnymi danymi, co najmniej na poziomie województwa, a jeśli to możliwe - gminy.

Tendencja wzrostu zużycia energii w gospodarstwach domowych, jaka miała miejsce w latach 20022010 w ostatnich latach uległa zahamowaniu, dzięki stosowaniu energooszczędnych materiałów budowlanych w nowo wznoszonych budynkach oraz termomodernizacji budynków starszych (wymiana okien, docieplenia, wymiana urządzeń grzewczych).

W badaniach własnych oszacowania bieżącego zużycia energii elektrycznej w gospodarstwach domowych dokonano w oparciu o dane literaturowe i dostępne dane statystyczne oraz zweryfikowano je w oparciu o badania ankietowe.

Główny Urząd Statystyczny corocznie publikuje dane statystyczne dotyczące funkcjonowania systemu energetycznego w kraju. Informacje te obejmują między innymi ilość rocznie zużywanej energii przez gospodarstwa domowe w przeliczeniu na jedną osobę [kWh/osoba/rok].

W celu sporządzenia bilansu energetycznego gminy, ilość energii zużywanej łącznie przez wszystkie gospodarstwa domowe $\left(\mathrm{A}_{\mathrm{GD}}\right)$ obliczono na podstawie poniższego wzoru:

$$
A_{\circlearrowleft}=l_{m} \cdot a_{j m}
$$

gdzie:

$\mathrm{l}_{\mathrm{m}}$ - liczba mieszkańców na analizowanym obszarze,

$\mathrm{a}_{\mathrm{jm}}$ - jednostkowe zużycie energii elektrycznej przez gospodarstwa domowe w przeliczeniu na osobę [kWh/osoba/rok].

Wskaźnik $\mathrm{a}_{\mathrm{im}}$ przyjęto na poziomie określonym dla NTS 4 . W cellu oceny wiarygodności obliczeń przeprowadzonych na podstawie danych statystycznych, analizę uzupełniono o wyniki badania ankietowego. W zależności od celu badań należy tak konstruować formularz ankiety, aby oszacować:

- średnie roczne zużycie energii w gospodarstwie domowym w kWh/rok,

- średnie roczne zużycie energii w gospodarstwie domowym na osobę w kWh/rok/osoba,

- średnie roczne zużycie energii na $\mathrm{m}^{2}$ powierzchni mieszkalnej,

- wyselekcjonować okresy najmniejszego i największego zużycia energii oraz określić różnicę między tymi wartościami.

Problemem metodologicznym analizy opartej na badaniach ankietowych może być ustalenie związku między wyrażanymi opiniami badanych a faktycznym zachowaniem respondentów. Próba rekonstrukcji relacji między tymi pojęciami jest szczególnie ważna, gdy narzędziem badawczym jest kwestionariusz ankiety, z którego wnioski wyciągane są na podstawie deklaracji respondentów, a nie bezpośredniej obserwacji ich zachowań. Powstaje zatem obszar niepewności dotyczący tego, czy udzielone odpowiedzi znajdą odzwierciedlenie w rzeczywistych działaniach. Nie zakłada się, że badani świadomie podają nieprawdziwe odpowiedzi, a jedynie poddaje $\mathrm{w}$ wątpliwość, na 
As part of the research the estimation of heat consumption on the basis of a methodology similar to the procedure for the energy certification of buildings was conducted. For this purpose, data were collected on the number of buildings constructed in particular time intervals. The advantage of using this procedure is in the objective assessment of the demand for energy, making the obtained results independent of individual customer behavior, with regard to manners of energy usage, such as maintaining excessively high or low temperature in the rooms. Values of the indicator of specific unit demand for heat, depending on the period of construction, used for calculations is shown in Table 3.

In the analysis of heat demand was the obtained results of the survey were also used. On this basis, the proportions between the consumption of primary fuels used for household heating and other household purposes were assessed. In addition, the results of the research allowed us to assess which resources are used exclusively for heating, and which are energy resources for hot water preparation and cooking. ile odpowiedzi wynikają z próby dostosowania się do ogólnie przyjętych zasad (Sidorczuk-Pietraszko, Zawistowska 2011).

W ramach badań przeprowadzono też oszacowanie zużycia ciepła na podstawie metodyki zbliżonej do procedury certyfikacji energetycznej budynków. W tym celu zebrano dane dotyczące liczby budynków wzniesionych $\mathrm{w}$ poszczególnych przedziałach czasowych. Zaletą wykorzystania tej procedury jest obiektywna ocena zapotrzebowania na energię, uniezależniająca uzyskane wyniki od indywidualnych zachowań odbiorców w zakresie sposobów korzystania z energii (np. utrzymywania nadmiernie wysokiej lub niskiej temperatury $\mathrm{w}$ pomieszczeniach). Wartości jednostkowego wskaźnika zapotrzebowania na ciepło w zależności od okresu budowy, wykorzystane do obliczeń, przedstawiono $\mathrm{w}$ tabeli 3.

W analizie zapotrzebowania na ciepło wykorzystano też wyniki przeprowadzonych badań ankietowych. Na ich podstawie oceniono proporcje pomiędzy zużyciem podstawowych paliw służących do ogrzewania mieszkań i na inne cele bytowe. Ponadto wyniki badań pozwoliły ocenić, które surowce służą wyłącznie do ogrzewania, a które znajdują energetyczne wykorzystanie do przygotowania c.w.u. i przyrządzania posiłków.

Table 3. The indicative heat demand indicator, depending on the age of the building

Tabela 3. Orientacyjny wskaźnik zapotrzebowania na ciepło w zależności od wieku budynku

\begin{tabular}{|c|l|c|}
\hline $\begin{array}{c}\text { Buildings } \\
\text { constructed in } \\
\text { years/ } \\
\begin{array}{c}\text { Budynki budo- } \\
\text { wane w latach }\end{array}\end{array}$ & \multicolumn{1}{|c|}{$\begin{array}{c}\text { The basal regulation and date of introduction/ } \\
\text { Podstawowy przepis i data wprowadzenia }\end{array}$} & $\begin{array}{c}\text { The indicative heat } \\
\text { consumption indica- } \\
\text { tor [kWh/m2/year]/ } \\
\text { Orientacyjny wskaź- } \\
\text { nik zużycia ciepła } \\
\text { [kWh/m2/rok] }\end{array}$ \\
\hline \multirow{2}{*}{ till/do 1966 } & $\begin{array}{l}\text { Construction Law (Journal of Laws 1994 No. 89 item. 414, as amended)/ Prawo } \\
\text { Budowlane (Dz.U. 1994 nr 89 poz. 414 z późn. zm): } \\
\text { - central and eastern part of Poland/ środkowa i wschodnia część Polski } \\
\text { - western part of Poland/ zachodnia część Polski }\end{array}$ & $240-280$ \\
\hline $1967-1985$ & $\begin{array}{l}\text { PN-64 /B-03404, from 01.01.1966 } \\
\text { PN-74/B-02020, from 01.01.1976 }\end{array}$ & $300-350$ \\
\hline $1986-1992$ & PN-82 / B-02020, from 01.01.1983 & $240-280$ \\
\hline $1993-1997$ & PN-91/B-20020, from 01.01.1992 & $160-200$ \\
\hline & $\begin{array}{l}\text { Regulation of the Minister of Infrastructure of 12 April 2002 on the technical } \\
\text { conditions to be met by buildings and their location (Journal of Laws No. 75, item. } \\
\text { as amended)/ } \\
\text { Rozporządzenie Ministra Infrastruktury z dn. 12 kwietnia 2002 r. w sprawie } \\
\text { warunków technicznych, jakim powinny odpowiadać budynki i ich usytuowanie } \\
\text { (Dz.U. Nr 75, poz. 690 z późn. zm.) }\end{array}$ & $120-160$ \\
\hline since/od 1998 & $90-120$ \\
\hline
\end{tabular}

Source: the authors' elaboration based on the above-mentioned regulations.

Źródło: opracowanie własne na podstawie wymienionych przepisów.

\section{Estimating power consumption in companies}

In terms of energy-consuming devices being used, companies are much more diverse than households. One can distinguish service-providing, manufacturing and retail companies, with only the latter being reasonably homogeneous in terms of using energy-consuming devices. In this type of companies, energy is consumed mainly for heating, lighting and powering electrical, such as refrigerators and refrigerated counters, ventilation and air

\section{Szacowanie zużycia energii w przedsiębior- stwach}

Przedsiębiorstwa są pod względem wykorzystywanych odbiorników energii znacznie bardziej zróżnicowane niż gospodarstwa domowe. Wyróżnia się przedsiębiorstwa usługowe, produkcyjne i handlowe, przy czym jedynie te ostatnie są w miarę jednorodne pod względem wykorzystywanych odbiorników energii. W przedsiębiorstwach tego typu, energia zużywana jest głównie na ogrzewanie, oświetlenie 
conditioning facilities in the summer and the supply of office equipment.

Service and industrial enterprises can have a very diverse character, so a detailed definition of the range of energy-consuming equipment used by them is difficult. These are usually electric motors used as drive units for different devices or resistancebased devices that convert electrical energy into technological heat. Company offices are usually equipped with: computers with monitors, laptops, fax machines, copying machines, printers, kettles, coffee machines, audio-video equipment and refrigerators.

Estimation of the energy demand for companies causes a number of difficulties. The use of indicators making energy consumption conditional upon the area occupied by a given company is not appropriate in this case, because some companies occupy a large area but consume very little energy (for example transport companies where garages and car parks occupy a lot of space) (Rusak 2011).

In our study the estimation of energy consumption in companies was carried out on the basis of the information on energy and energy fuel consumption in the recipients covered by the survey research. The total annual energy consumption of companies in a given commune was estimated in accordance with the following formula:

$$
A_{p}=\frac{\sum_{l_{p}}^{L_{p}} A_{n}\left(l_{p}\right)}{L_{p}} L_{p}
$$

where:

$L_{\text {p }}$ - number of surveyed companies in the study sample,

$L_{p}$ - number of companies in a commune,

$A_{n}^{p}$ - annual energy consumption of the company $l_{m}$.

It is important that companies are equipped with separate meters of the energy used only within the company itself, which allows for making an assessment of electricity consumption for conducting economic activity. While conducting the survey, it is important that the consumption of raw materials is given separately for residential buildings and separately for buildings associated with commercial activity.

\section{Estimation of electricity consumption on farms}

The method of energy usage on farms depends on the type of production they conduct. The production determines types of electrical devices which are used and the requirements for heating of buildings, and therefore the demand for heat.

Traditional farms with multi-directional production are the type of customers whose energyconsuming equipment is the most diverse. This diversity is even greater if we consider collectively oraz zasilanie odbiorników w postaci lodówek i lad chłodniczych, wentylację i klimatyzację pomieszczeń w okresie letnim oraz zasilanie urządzeń biurowych.

Przedsiębiorstwa usługowe i przemysłowe mogą mieć bardzo różnorodny charakter, dlatego szczegółowe określenie zbioru stosowanych urządzeń wykorzystujących energię jest trudne. Najczęściej są to silniki elektryczne stosowane jako jednostki napędowe różnych urządzeń lub urządzenia oporowe zamieniające energię elektryczną na ciepło technologiczne. Biura przedsiębiorstw są wyposażone najczęściej w: komputery z monitorami, laptopy, faksy, kopiarki, drukarki, czajniki, ekspresy do kawy, sprzęt audio-video, lodówki.

Szacowanie zapotrzebowania na energię dla przedsiębiorstw nastręcza szereg trudności. Niewłaściwe jest w tym przypadku wykorzystanie wskaźników uzależniających zużycie energii od powierzchni zajmowanej przez przedsiębiorstwa, gdyż część przedsiębiorstw, mimo teoretycznie dużej zajmowanej powierzchni, zużywa niewielkie ilości energii (na przykład firmy transportowe zajmujące duży obszar na cele garażowe i parkingowe) (Rusak 2011).

W badaniach własnych oszacowanie zużycia energii $\mathrm{w}$ przedsiębiorstwach przeprowadzono na podstawie informacji o zużyciu energii i surowców energetycznych u odbiorców objętych badaniem ankietowym. Całkowite roczne zużycie energii $\mathrm{w}$ przedsiębiorstwach $\mathrm{w}$ gminie oszacowano według zależności:

$$
A_{p}=\frac{\sum_{l_{p}}^{L_{p}} A_{n}\left(l_{p}\right)}{L_{p}} L_{p}
$$

gdzie:

$L_{p_{p}}$ - liczebność próby badanych przedsiębiorstw,

$L_{p}$ - liczba przedsiębiorstw w gminie,

$A_{n}{ }^{p}$-roczne zużycie energii w przedsiębiorstwie $l_{m}$.

Istotne jest, aby firmy były wyposażone w oddzielne liczniki energii zużywanej wyłącznie w przedsiębiorstwie, co pozwoli na ocenę zużycia energii elektrycznej na prowadzenie działalności gospodarczej. Prowadząc badanie ankietowe należy mieć na uwadze, aby podawane było zużycie surowców opałowych odrębnie dla budynków mieszkalnych, a odrębnie dla budynków związanych z prowadzoną działalnością gospodarczą.

\section{Szacowanie zużycia energii elektrycznej w gospo- darstwach rolnych}

Sposób wykorzystywania energii w gospodarstwach rolnych zależny jest od rodzaju prowadzonej przez nie produkcji, która determinuje typy wykorzystywanych urządzeń elektrycznych oraz wymagania w stosunku do ogrzewania budynków, a co za tym idzie zapotrzebowania na ciepło.

Gospodarstwa tradycyjne, o produkcji wielokierunkowej, są tym typem odbiorców, którego wypo- 
the energy-consuming devices associated with agricultural production and those used in rural households. The research on the equipment of this group of recipients in devices powered by electricity shows that there is a correlation between the amount of energy consumed and the power of the installed devices, the number of people and the agriculturally usable area of the farm (Jaworski, Piechocki 2005). Energy consumption in Polish agriculture is changing (Fig. 2), with the decrease of the number of farms, along with the increasing area of arable land per one farm and more rational use of machinery and equipment (Pawlak 2009). sażenie w odbiorniki energii jest najbardziej zróżnicowane. Zróżnicowanie jest jeszcze większe, jeśli rozpatruje się łącznie odbiorniki związane z produkcją rolniczą oraz te wykorzystywane w wiejskich gospodarstwach domowych. Z badań nad wyposażeniem tej grupy odbiorców w urządzenia zasilane energia elektryczną wynika, że istnieje korelacja pomiędzy ilością zużywanej energii a mocą zainstalowanych urządzeń, liczbą osób oraz powierzchnią użytków rolnych w gospodarstwie (Jaworski, Piechocki 2005). Zużycie energii w polskim rolnictwie ulega zmianom (rys. 2), wraz ze zmniejszaniem liczby gospodarstw, zwiększeniem powierzchni użytków rolnych przypadających na jedno gospodarstwo i bardziej racjonalnym wykorzystaniem maszyn i urządzeń (Pawlak 2009).

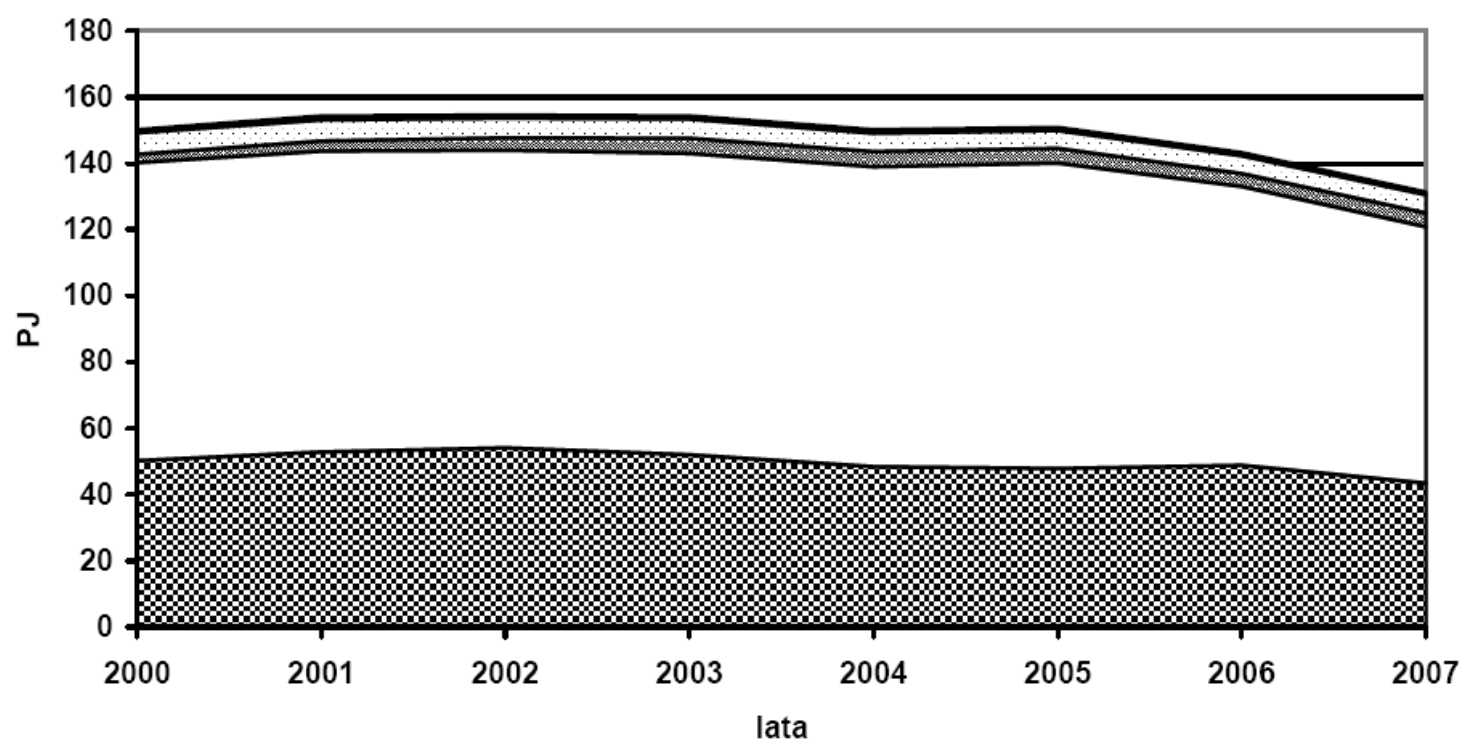

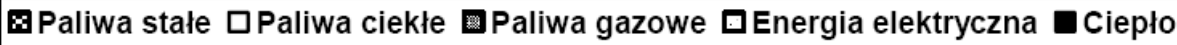

Legend/Legenda:

Solid fuels - Paliwa stałe

Liquid fuels - Paliwa ciekłe

Gas fuels - Paliwa gazowe

Electric energy - Energia elektryczna

Heat - Ciepło

Figure 2. The level and type structure of energy carrier consumption in Polish agriculture Rysunek 2. Poziom i struktura rodzajowa zużycia nośników energii w rolnictwie polskim

Source: Pawlak, 2009.

Źródło: Pawlak 2009.

Analyses concerning the level of energy consumption by agricultural production often employ an indicator of electrical energy consumption in agriculture per one hectare of farmland. While estimating the demand for electricity, it is important that the energy consumed in rural households is not counted twice; first as the energy used for household purposes, and secondly as the energy used for production purposes in agriculture. Lack of distinction between the energy used for the two above-
W analizach dotyczących energochłonności produkcji rolniczej często stosowany jest wskaźnik zużycia energii elektrycznej w rolnictwie w odniesieniu do jednego hektara uży tków rolnych. Przy oszacowaniu zapotrzebowania na energię elektryczną trzeba zwrócić uwagę na to, by energii zużywanej w gospodarstwach wiejskich nie policzyć dwukrotnie, raz jako energii zużywanej na cele gospodarstwa domowego, a drugi raz jako energii wykorzystywanej na cele produkcyjne $\mathrm{w}$ rolnictwie. Brak rozróżnienia 
mentioned separate purposes creates a problem with estimating the actual energy consumption by agriculture in a given commune (Pawlak 2009; Rusak 2011; Trojanowska 2002). It should also be noted that changes in qualifying energy consumption in rural areas for CSO reports took place in 2005. (Areas ... 2013).

In our research the estimation of energy consumption on farms, exclusively for production purposes, proved impossible on the basis of surveys. Farmers participating in the study generally did not have separate electricity meters for households and farms. Therefore, the assessment of electricity consumption by farms was made on the basis of statistical data and specialist literature and verified on the basis of the survey results. For this purpose, the data published by the CSO were used, including electricity consumption in agriculture (only for agricultural production) and the area of farmed land in particular provinces (Consumption ... 2014). The energy consumption in kWh per hectare of farmed land was estimated on this basis. This rate was used to calculate the energy consumption in the surveyed communes. It should be noted that this estimation may be seriously flawed because agriculture is very different in each province and the differences at the communal level may be even greater. The intensity of production in communes with good quality soil is high and farmers bear large expenditures (including expenditures on energy) which enables them to obtain high economic efficiency. Specific energy consumption in communes with less favorable soil conditions may be significantly lower.

\section{Conclusions}

The scope and details of information required to be obtained during the preparation of an energy balance statement for a local government unit depends on the purpose of the developed analysis. A number of guides and training materials have been developed. They are helpful in balancing energy demands and sources necessary to meet those demands in the context of reducing emissions, reducing energy consumption, implementation of renewable energy technologies and the idea of sustainable development. In practice, the use of one particular methodology may prove to be difficult and may require a combination of different approaches and a modification of the manuals compiled previously. Statistical and literature data may be useful, but it is advisable to verify the obtained results basing on survey research conducted in the conditions of one particular territorial unit. na energię wykorzystywaną na wyżej wymienione dwa odrębne cele stwarza problem z oszacowaniem rzeczywistej energochłonności rolnictwa na terenie gminy (Pawlak 2009; Rusak 2011; Trojanowska 2002). Należy też mieć na uwadze, że zmiany w zakresie kwalifikowania zużycia energii na obszarach wiejskich do sprawozdań GUS miały miejsce w 2005 r. (Obszary... 2013).

W badaniach własnych oszacowanie zużycia energii w gospodarstwach rolnych wyłącznie na cele produkcyjne okazało się niemożliwe w oparciu o badania ankietowe. Rolnicy biorący udział w badaniu w zdecydowanej większości nie posiadali oddzielnych liczników energii dla gospodarstw domowych i rolnych. W związku z powyższym ocenę zużycia energii elektrycznej przez gospodarstwa rolne sporządzono na postawie danych statystycznych, specjalistycznej literatury oraz zweryfikowano na podstawie wyników badań ankietowych. W tym celu posłużono się danymi publikowanymi przez GUS, obejmującymi zużycie energii elektrycznej w rolnictwie (wyłącznie na produkcję rolną) oraz powierzchni użytków rolnych w poszczególnych województwach (Zużycie... 2014). Na tej podstawie oszacowano wielkość zużycia energii elektrycznej w kWh na hektar użytków rolnych, który to wskaźnik wykorzystano do obliczenia zużycia energii w badanych gminach. Należy zaznaczyć, że oszacowanie to może być obarczone dużym błędem, gdyż rolnictwo w poszczególnych województwach jest bardzo zróżnicowane, a różnice te na poziomie gminy mogą być jeszcze większe. Intensywność produkcji w gminach gdzie występują gleby dobrej jakości jest wysoka, a rolnicy ponoszą duże nakłady (w tym nakłady na energię), uzyskując wysoką efektywność gospodarowania. Jednostkowe zużycie energii w gminach o mniej korzystnych warunkach glebowych może być znacząco niższe.

\section{Podsumowanie}

Zakres i szczegółowość informacji, potrzebnych do pozyskania przy sporządzaniu bilansu energetycznego danej jednostki samorządu terytorialnego, zależą od celu opracowania analizy. Opracowano szereg poradników i materiałów szkoleniowych, pomocnych przy bilansowaniu zapotrzebowania na energię i źródeł zaspokojenia tych potrzeb, w kontekście ograniczenia emisji, zmniejszenia zużycia energii, wdrażania technologii OZE czy idei zrównoważonego rozwoju. W praktyce zastosowanie konkretnej metodyki może okazać się trudne i wymaga łączenia różnych podejść oraz modyfikowania opracowanych wcześniej poradników. Użyteczne mogą okazać się dane statystyczne i literaturowe, jednak wskazane jest weryfikowanie uzyskanych wyników w oparciu o badania ankietowe prowadzone w warunkach konkretnej jednostki terytorialnej. 


\section{References/ Literatura:}

1. Bertoldi P., Bornás Cayuela D., Monni S., Piers de Raveschoot R. (2012), Poradnik. Jak opracować Plan działań na rzecz zrównoważonej energii (SEAP). Stowarzyszenie Gmin Polska Sieć „Energie Cités”, Kraków.

2. Bukowski Z. (2012), Możliwości prawne wprowadzenia zakazu spalania określonych paliw stałych na terenie gminy. Studia z Zakresu Prawa, Administracji i Zarządzania UKW, t. 1, s. 45-59.

3. Efektywność wykorzystania energii w latach 2003-2013 (2015), GUS, Warszawa.

4. Jaworski J., Piechocki J. (2005), Wpływ niektórych czynników na wielkość i strukturę zużycia energii elektrycznej w gospodarstwach wiejskich. Inżynieria Rolnicza, nr 6, s. 243-250.

5. Obszary wiejskie. Powszechny spis rolny 2010 (2013), GUS, Warszawa, Olsztyn.

6. Pawlak J. (2009), Nakłady energii w rolnictwie polskim i ich efektywność. Problemy Inżynierii Rolniczej, nr 1, s. 87-94.

7. Polityka Energetyczna Polski do roku 2030. Dokument przyjęty przez Rząd Rzeczypospolitej Polskiej w listopadzie 2009 r.

8. Powszechny Spis Rolny (2011), GUS, Warszawa.

9. Rozporzq̨dzenie Ministra Infrastruktury z dnia 6 listopada 2008 r. zmieniajq̨ce rozporzqqdzenie w sprawie warunków technicznych, jakim powinny odpowiadać budynki i ich usytuowanie. Dz.U. nr 201, poz. 1238 z późn. zm.

10. Rusak H. (2011), Gospodarowanie energiq w gminach - podstawy metodyczne. WSE w Białymstoku, Białystok.

11. Sidorczuk-Pietraszko E., Zawistowska A. (2011), Stan gospodarowania energiq $w$ gminach w świetle wyników badań. WSE w Białymstoku, Białystok.

12. Trojanowska M. (2002), Analiza popytu na energię elektrycznq odbiorców wiejskich. Wiadomości Elektrotechniczne, nr 10-11, s. 403-405.

13. Trojanowska M., Szul T. (2008), Analiza statystyczna zapotrzebowania na ciepło w gminach wiejskich. MOTROL, nr 10, s. 126130.

14. Ustawa z dnia 7 lipca 1994 r. Prawo budowlane. Dz.U. 1994 nr 89 poz. 414 z późn. zm.

15. Wartości opałowe (WO) i wskaźniki emisji $\mathrm{CO}_{2}$ (WE) w roku 2014 do raportowania w ramach Wspólnotowego Systemu Handlu Uprawnieniami do Emisji za rok 2017 (2016), KOBIZE, Warszawa.

16. Zarządzanie energią w budynkach komunalnych. Poradnik (2009), Stowarzyszenie Gmin Polska Sieć „Energie Cités”, Kraków. 